\title{
NORMAS JURÍDICAS DO COMÉRCIO MUNDIAL: PROPRIEDADE INTELECTUAL
}

Luiz Otavio Pimentel"

SUMARIO: 1- Introducão. 2. OMC. 2.1-Antecedente. 2.2-Exchsão da clabula social. 2.3" Propredade intelectud e GATT. 2.4-Interesses protegidos pelo GATT. 2.5-Constituica da

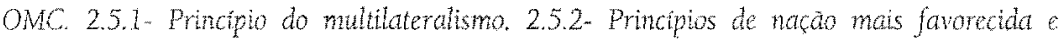
probicăo de discriminaçoes. 2.5.3-Principio da conservaçấo do meio ambiente. 2.6- Efeitos da

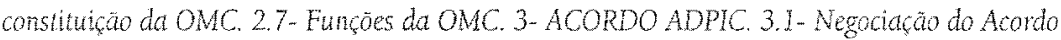
ADPIC seus principas atores. 3.2 Por gue um regine jurdico minimo para a propriedade intelecual? 3.3-Objetivos do Acordo ADPIC. 4-Condusäo. 5- Bibliografia.

SUMMARY: 1-Introduction. 2-OMC. 2.1 - Antecedent 22- Exchusion of the social clause. 2.3 - Intellectual Property and GATT. 2.4 - Interests protected by GATT. 2.5-Constitution of OMC. 2.5.1- principle of the multilateralsm. 2.5.2 - Principle of the more favored nation and prohibition of discriminations. 2.5.3 - Principle of the conservation of the ewvironment. 2.6 . clects of the constitution of OMC. 2.7 - Functions of OMC. 3-ADPICs Treat. 3.1-negotiation of the ADPICs Treat and you principal actors. 3.2 Why a minimum juridical regim for the intellectual property? 3.3 . Objectives of the ADPIC's Treat. 4 - Condusion. 5 - Bibliography.

ÜBERSICHT: 1- Enfuhrung. 2. WTO. 2.1. Vorgeschichte. 2.2. Ausschluss der Sozialklausel. 2.3. Geistiges Eigentum und GATT. 2.4. Vom GATT geschütze Interessen. 2.5. Verfassung der WTO 2.5.1. Grundakz der Mehreitigheit. 2.5.2. Gnudsatz der Meisbeginstigung und des

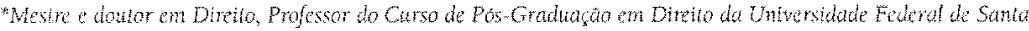

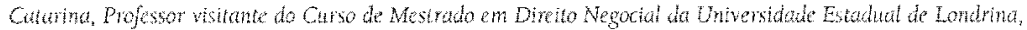

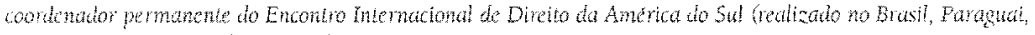
Urigrat, Argentina, Chlle E Bolvia).
} 
Diskriminierungsverbotes. 2.5.3. Grundsatz der Bewahrung der Umwelt. 2.6. Wirkungen der Verfassung der WTO. 2.7. Aufgaben der WTO. 3.Der ADPIC Vertrag. 3.1. Die Verhandlungen anlässlich des ADPIC und ihre Hauptbeteiligten. 3.2. Wozu eine rechtiche Mindestregelung des geistigen Eigentums? 3.3. Ziele des ADPIC.4. Schlussfolgerung. 5. Bibliographie.

RESUMO: O artigo trata da produção dos textos do Direito do Comércio Mundial, tendo por marco de análise o processo de globalização econômica e por exemplo a propriedade intelectual.

ABSTRACT: The article treats of the production of the texts of the Right of the World Trade, tends for analysis mark the process of economical globalization and for instance the intellectual property.

ZUSAMMENFASSUNG: Die Abhandlung behandelt die Herstellung von Texten des Welthandelsrechts und nimmt als Grundlage den wirtschaftichen Globalisierungsprozess und als Beispiel das intellektuelle Eigentum.

PALAVRAS-CHAVE: Direito do Comércio Mundial. Propriedade Intelectual. Organização Mundial do Comércio.

KEY-WORDS: Right of the World Trade. Intellectual Property. World Organization of the Trade.

SCHLÜSSELWÖRTER: Welthandelsrecht. intellektuelles Eigentum. Welthandelsorganisation.

\section{Introdução}

Q assunto abordado neste artigo'é o contexto de produção das normas jurídicas para o comércio, tendo por marco a fase atual do processo de mundialização do Direito, centrando-se na propriedade intelectual. 0

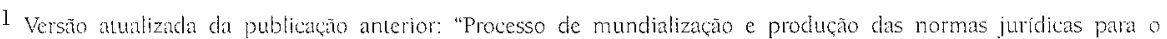
comércio: o caso da proprieclade industrial" (1998).
} 
momento caracteriza-se pelas transformaçoes do Direito requeridas pelos agentes economicos, resultando no fato de que uma parte importante do sistema normativo escapa do seu tradicional centro de producão que era o legislativo nacional e passa para o âmbito das organizaçōes internacionais. 0 campo da propriedade intelectual é um ramo especial que ifustra bem este fenômeno, pois partiram do acordo constitutivo da Organização Mundial do Comércio $(\mathrm{OMC})^{2}$ as normas que devem ser integradas nos sistemas jurídicos nacionais, elaboradas como preceitos mínimos e programáticos. Assim foi possível dar mais um passo na harmonizaça das normas para o comércio necessárias à mundialização ou globalização.

\section{OMC}

Do ponto de vista econômico-comercial e institucional, o processo de mundialização tem uma ligação bastante íntima com uma instituição de mais de cinquenta anos, pois está ligado como por um cordāo umbilical ao Acordo Geral sobre Tarifas Alfandegárias e Comercio (GATT) ${ }^{3}$ de 1947. De modo que para tratar da OMC é imprescindivel conhecer o antecedente GATT e seu principal foro de negociaçoes, que foi a Rodada Uruguai.

\section{1- Antecedente}

O GATT teve por objetivo fundamental a liberalização do comércio internacional. Foi regido por três princípios básicos: tratamento igual e não discriminatótio, para todas os paises membros; redução de tarifas por meio de negociaçóes; e, eliminação das cotas de importação - todos para assegurar o funcionamento do princípio fundamental do sistema que é o de livre comércio.

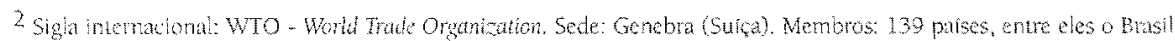
(novembro de 2000). Secretaria: 500 pessoss. Direor-geral: Mike Moore (Nowa Zelandia). Fonte:

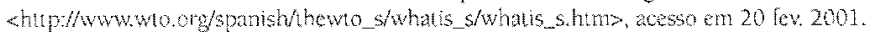

3 GATT: Conerul Agroment on Tails and Trade.

4 Ver: MANGAS MARTN, 1996. p.344. Sobre a diferemca estrutural ente GAT E OMC ver BARRAL, 1996. p.370.
} 
A iniciativa da constituição do GATT data de 1946, quando o Conselho Econômico e Social da Organizaçăo das Naçoes Unidas (ONU) convocou a Convenção Internacional sobre Comércio e Emprego, reunida no ano seguinte, em Havana. Época em que imperavam as idéias de KEYNES. Durante a convenção se elaborou uma carta para promover a criação de uma organização internacional de comércio, que não chegou a entrar em vigor. As causas do fracasso se situaram entre duas balizas: o inicio das desavenças dos norte-americanos com os soviéticos, na chamada guerra fria, e a decisăo do Senado dos Estados Unidos de negar a ratificação da carta, por considerar que a nova organização não era suficientemente partidária do livre comércios.

Entretanto, dos trabalhos preparatórios da Convenção, resultaram as negociaçóes comerciais e de tarifas alfandegárias formalizadas no que se passou a denominar GATT, com caráter de foro permanente e tendo por fim liberalizar o comércio. Entre os principais acordos alcançados, foram proibidos os comportamentos contra a cláusula de nação mais favorecida para todos os seus membros (exceto para os mercados comuns, zonas de livre comércio e casos de waivers, aprovados por dois tercos dos seus membros), as práticas de comércio desleal do tipo dumping ${ }^{7}$, os subsidios ${ }^{8} \mathrm{e}$ as distorçoes de mercado.

Desde a sua criaçẫo, negociou-se no GATT, a redução dos impostos e outras barreiras relativas ao comércio, como as restrições quantitativas, os sistemas de avaliação e as políticas agrícolas.

\footnotetext{
5 TAMAMES, GALLEGO, 1996, D.14M.15. MANGAS MARTIN, 1996, p.344.

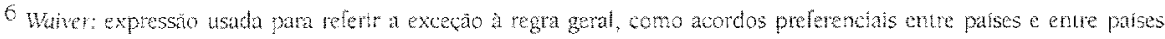
integlabos c lereelos no sein do GATT.

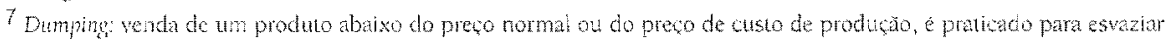
grandes estoques, ou para desbancar outros concorrentes num merado, ou para alcangar séries de produço que pela

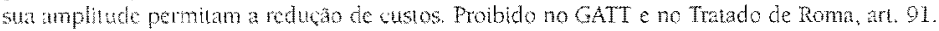

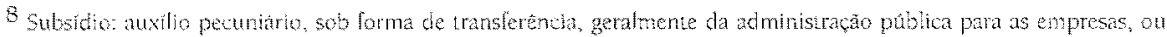
familas, ou insthuçes sem frm lucrativo, desmadas a minimizar perdas, fomentar atividades due possam

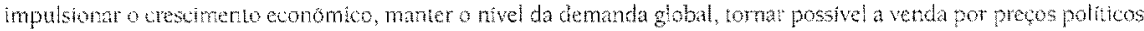

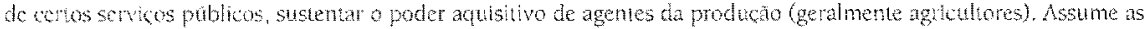

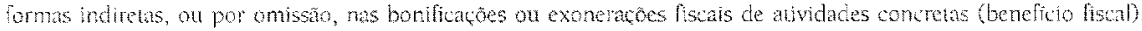
TAMAMES,GALLEGO, 1906, p.587.
} 
$O$ documento fundacional do GATT reflete os princípios neoliberais, segundo os quais o comércio sem travas é essencial para obter o pleno aproveitamento dos recursos mundiais, a elevação do nível de vida, a obtenção do máximo emprego, o aumento de ingressos ${ }^{9}$ reais, o crescimento da produção nundial e os intercâmbios de produtos ${ }^{10}$.

Logicamente, a orientação para o livre comércio favorece a situação privilegiada dos países mais industrializados em detrimento dos países subdesenvolvidos. Sendo necessário lembrar que o seu princípio fundamental tem sido contrariado reiteradamente pelos membros industrializados que protegem seus mercados, por diferentes motivos, cujos efeitos resultam na restriçăo do acesso por parte dos paises menos desenvolvidos ${ }^{13}$.

As negociaçôes do GATT foram chamadas de Rodadas, oito no total, sendo a Uruguai a mais famosa e dela havendo participado a maioria dos paises do mundo e a Uniäo Européia como tal, significando a quase totalidade do volume de comércio do planeta.

A Rodada Uruguai do GATT, iniciada em 1986, chegou a um acordo final para a ampla liberalização do comércio de mercadorias e de serviços com a criação da $\mathrm{OMC}$. Entre os anexos setoriais desse Acordo figura o que trata dos Aspectos dos Direitos de Propriedade Intelectual relacionados ao Comércio (ADPIC), que abrange as patentes.

A duração dessa rodada de negociaçōes, cerca de oito anos, evidencia o quanto foi intrincado o processo, uma vez que tratava de seguir avançando na liberalização do comércio mundial, ao mesmo tempo em que abarcava novas áreas, condensayam-se normas esparsas e se explicitavam muitas das regras seguidas no GATT, exceçöes e procedimentos, para permitir o funcionamento de um sistema normativo no âmbito das relaçoes comerciais internacionais ${ }^{12}$.

\footnotetext{
9 "Ingresso" ha linguagem conomica signiflea as guamtidades que säo pagas on devidas a una empresa, em lloca da venda de scus produos ou prestayo de servico

10 ZUCOHERNO, MTELMAN, 1997,034 .

11 SANDRONI, 1994, p.151.

12 TUGORES QUES, 1996, p.68.
} 


\section{2- Exclusão da cláusula social}

A expressão cláusula social foi usada durante a fase de negociaçöes da OMC, na Rodada Uruguai do GATT, para designar as medidas que poderiam ter sido adotadas para impedir o "dumping social", que consiste nos baixos salários pagos pelos agentes econômicos instalados nos paises do Terceiro Mundo.

O fenômeno conhecido por dumping social ocorre por força da "deslocalização"13 de industrias e de centros de produção.

Com efeito, a necessidade politica de corresponder ao processo de desenvolvimento do capitalismo fez com que os govemos de vários Estados, principalmente os asiáticos, passassem a conceder significativas ajudas às mega-empresas estrangeiras ou locais para que o fluxo de investimento, produção e comercialização pudessem ocorrer desde seus territórios.

Além das vantagens governamentais e outras de natureza estratégica, razão menos ética possibilitou também a opção aos agentes econômicos que trafegam mundialmente de se instalarem no Terceiro Mundo, promovendo o dumping social em razão dos baixos salários e precárias condiçōes de segurança e proteção dos trabalhadores.

Países considerados emergentes, alguns com um ritmo de industrializaçăo hoje bem acentuado, outros nem tanto, destacando-se a título de exemplo a China, Coréia do Sul, índia, Macau, Malásia, Paquistão, Singapura e Tailândia, permitiram uma série de vantagens com relação à força de trabalho que foram atrativas às empresas estrangeiras.

Desta maneira, os atores economicos contaram (e ainda contam) com mão-de-obra qualificada e habituada ao trabalho industrial por um custo inexpressivo. Quer dizer, praticando o mais puro capitalismo manchesteriano que indignava a MARX e ENGELS no século passado. Jomadas de trabalho intermináveis, sem descanso semanal ou férias anuais, trabal ho menos vantajoso para as mulheres e a escravização da infância - sem falar nas condiçôes de higiene e segurança.

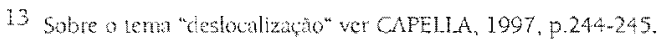


Os governos do mundo industrializado, europeu principalmente, não queriam aceitar o livre comércio competindo com estruturas sócio-laborais tăo vantajosas para o capital. Certamente, incitados por uma sociedade que teme a perda dos beneficios do Estado de bem-estar e das conquistas sociais de mais de um século de lutas entre capital e trabalho. Manifestou-se também um espirito altaneiro: queriam evitar um ritmo de super-exploração da mào-de-obra, insustentável no futuro, que poderia levar a problemas sociais de dificil previsão ${ }^{14}$.

E lógico que os paises emergentes também promoveram o desenvolvimento dos recursos humanos e tecnológicos, de modo que haveria o risco de que a competição mundial pudesse afetar empresas de menor envergadura, com menos possibilidades de concorrencia no comércio global. Para elas a desvantagem podia significar um estancamento tecnológico.

Entretanto, o quadro acima evidencia que o peso do "Tobby" das mega-empresas que buscam mão-de-obra barata pendeu na balança das negociaçōes, assim como uma reduçáo média de $33 \%$ das taxas allandegárias para os produtos dos paises desenvolvidos em novos mercados dos países do Terceiro Mundo - de modo que a "cláusula social" ficou fora do Acordo de Marraqueche ${ }^{15}$.

\section{3- Propriedade intelectual e GATT}

A inclusäo da propriedade intelectual no GATT foi devida basicamente a dois conjuntos de acontecimento, efeitos de política economica exterior.

Pximeiro, ao fracasso das medidas unilaterais e do bilateralismo protagonizados pelos Estados Unidos e pela União Européia. Coube, no entanto, aos Estados Unidos o impulso para a solução multilateral que elevou o nivel da proteção da propriedade intelectual. Este progresso

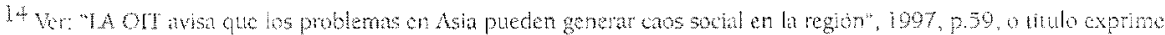

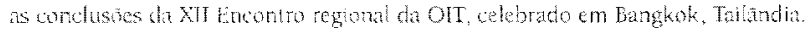

14 MANGAS MARTI, $1996,0.362$
} 
substantivo veio a ser conseguido, então, pelo tratamento do problema como uma prática comercial desleal no âmbito do GATT, com o pressuposto de que a falta de proteção acarreta a concorrência desleal ${ }^{16}$.

Em segundo lugar, deveu-se à insatisfação gerada nos países ricos pela incapacidade e lentidão para conseguir a ampliação da proteção da propriedade intelectual no seio da Organização Mundial da Propriedade Industrial (OMPI), órgão especializado da ONU. Esta situação acabou por facilitar a mudança de âmbito do tratamento normativo do tema, transferido definitivamente para o GATT, onde as negociações eram mais atrativas devido às perspectivas de abertura de mercados internacionais ${ }^{17}$.

Na OMPI se produziu um bloqueio político pela ação de grandes blocos de países que, atuando como uma só voz, não levavam em conta as peculiaridades de cada um. No âmbito do GATT, com toda a variedade de temas comerciais, era muito difícil que se produzisse esse voto mecânico por blocos. Os interesses econômicos acabaram prevalecendo sobre a retórica ideológica, principalmente pelas vantagens barganhadas individualmente. Os países desenvolvidos conseguiram desintegrar o Grupo dos 77, composto por países em vias de desenvolvimento e subdesenvolvidos, levando à prática a máxima do "divides e vencerás"18.

Assim, dentro do marco da liberalização do comércio mundial, as negociações do Acordo ADPIC comprometeram os Estados-membros da OMC a protegerem adequadamente em suas legislações internas a propriedade intelectual ${ }^{19}$.

Algumas desvantagens apontadas para o tratamento das questões da propriedade intelectual no seio do. GATT, no que toca às patentes, foram: a falta de pessoal qualificado no GATT (enquanto abundavam os especialistas

\footnotetext{
16 A idén de tratar os problemas da proteçao da propriedade industrial no GATT conston da declaracão de Punta del Este, lirmada em 20/9/1.986, que deu inicio a Rodada Uruguai, entre os temas novos para negociaçoes estavam os aspecios dos direitos de propriedade intelectual relacionados com o comércio, sigla ADPIC (TRIP's: Trade Related Aspects of Intellectual Property Rights).

17 Ver: PORZIO, 1996, p.409-410. LOBATO GARCIA-MIJAN, 1997, p.240.

18 Entre os integrantes do Grupo: Brasil e Índia. GÓMEZ SEGADE, 1996, p. 44.

19 MASSAGUER FUENTES, 1995, p.169.
} 
neste tema na OMPI); o risco de duplicação inútil de trabalho entre OMPI e GATT; o debilitamento do sistema tradicional apoiado em grandes convençoes administradas pela OMPI; a possibilidade de colocar em perigo o sistema de live comércio, porque os norte-americanos mais entusiastas com a iniciativa GATT eram dos setores industriais que se beneficiavam da poltica de subvençes, entre eles o farmacêutico ${ }^{20}$.

As principais vantagens de tratar da propriedade intelectual. particulamente as patentes, no GATT foram: a possibilidade de uma saida para o impasse em que se encontrava a OMPI, depois do fracasso para revisar a Convençăo da Uniăo de Paris; a existência de um âmbito de negociaçoes global no qual se poderiam oferecer e obter contrapartidas pelo respeito aos direitos de propriedade industrial; a menor probabilidade de que houvesse um enfrentamento entre blocos de paises com vantagem dos menos industralizados como na OMPI; e a possibilidade da disposicão de um mecanismo eficaz para a solucão de conllitos. As duas útimas, segundo GOMEZ SEGADE, foram as vantagens decisivas ${ }^{21}$.

No tocante à solucão de conflitos, o mecanismo da OMPI não era satisfatorio, pois mesmo prevendo que os casos de desavenca entre paises não solucionados por negociaçoes poderiam ser levados perante a Conte Internacional de Justiça de Haia, nunca se registrou a intervençäo desta conte para temas de propriedade intelectual, pois certamente haveriam implicacoes politicas que nenhum Estado desejaria arrostar ${ }^{22}$.

\section{4- Interesses protegidos pelo GATT}

Segundo GOMEZ SEGADE, desde o momento em que os Estados Unidos, juntamente com as potências mais industrializadas, optaram por incrementar a proteçäo da propriedade intelectual através do GATI, ficou claro que se tratava de proteger os interesses dos paises mais desenvolvidos.

\footnotetext{
20 GOMEZ SEGADE, 1996, p.44.

21 GOMEZ SEGADE, 1996, p.44.

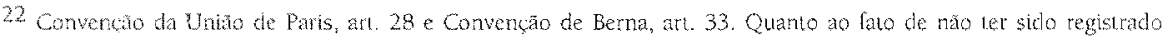
nerthum rewro a Conte de Hala, ver o relato do seu ex-Diretot-Geral: BOGSCH, 1983, p.51.
} 
E que os paises menos desenvolvidos, evidentemente, perceberam a estratégia dos países industrializados e os riscos potenciais deste tema ser tratado no âmbito do "Clube dos Ricos", que constituía o GATT. Esta situaça levou os paises menos desenvolvidos a invocarem argumentos jurídicos, como a lalta de competencia do GATT para ocupar-se da matéria, tendo em vista que ela estava atribuida na esfera internacional à OMPI. Entretanto, o argumento de oposiçăo năo vingou por muito tempo e os próprios diretores-gerais do GATT e da OMPI declararam que não existia obstáculo de competência para que o GATT tratasse da matéria ${ }^{23}$.

No mesmo sentido opina MASSAGUER FUENTES, dizendo que sob o propósito de eliminar as distorçôes que uma inadequada proteçào da propriedade industrial e comercial produz no comércio internacional, os negociadores se aproveitaram das peculiaridades do marco institucional para, em última instância, assegurar no mundo todo padrōes de proteção juridica unilormes, em particular equivalentes aos que existem nos paises desenvolvidos, tarefa que até entâo não havia logrado exito a OMPl${ }^{24}$.

A relação entre o comércio e a propriedade intelectual foi um verdadeiro "matrimónio de interesses" que ninguém poderia imaginar antes, considerando que os direitos de propriedade intelectual não são nem produto e nem serviço. No entanto, muitas das licenças derivadas dos direitos de propriedade intelectual formam parte do comércio intemacional de serviçose, por isso, não poderiam ficar à margem da negociação do GATT que se ocupava dos serviços, como loi a Rodada Uruguai ${ }^{25}$.

\section{5- Constituição da OMC}

A OMC é un organismo internacional, multilateral, para construção, defesa e desenvolvimento do sistema mundial de comércio. Servindo como

\footnotetext{
23 GONTZ SEGADE, 1996, p.45 46. No mesmo senido PACON, 1997, p.137-170.

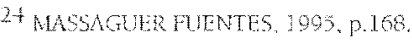

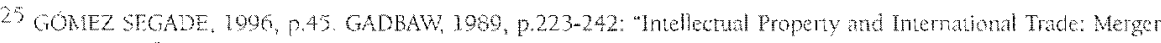

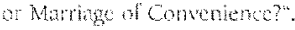


marco institucional comum para o desenvolvimento das relaçōes comerciais mundiais ${ }^{25}$

A OMC foi criada pelo Acordo de Marraqueche, também designado por Acordo OMC, firmado em 15 de abril de 1994 e vigorando desde $1^{\circ}$ de janeiro de 1995\%. No aspecto da sua natureza juridica, trata-se de uma organização internacional em sentido estrito, independente orgânica $e$ funcionalmente, com personalidade juridica de Direito Intemacional Público. Não está dotada de recursos destinados às necessidades de seus membros, como ocorria com as instituições de Bretton Woods, o FMI e o BIRD, e nem subordinada à ONU. Foi estabelecida por acordo entre seus membros, cujo instrumento internacional forma uma unidade complexa, porque a sua composição estrutural contém o Acordo constitutivo e mais quatro anexos, também com status de acordos internacionais e relativa autonomia, entre os quais está o ADPIC ${ }^{28}$.

A OMC tem capacidade de iniciativa própria e funcional, com os seguintes órgãos: a Conferência Ministerial, o Conselho Geral, os Conselhos setoriais (entre eles o Conselho do ADPIC) e a Secretaria Geral.

Quanto às decisões na OMC, mantém-se a prática do consenso, como no GATT, sendo previstas diversas espécies de maioria quando a unanimidade não for possivel.

Os Estados-membros e diversos Conselhos podem promover emendas nos acordos, inclusive no constitutivo. O procedimento de votação é variável segundo o conteúdo das alterações e os acordos $e$ anexos aletados. As emendas devem ser aprovadas pela Conferencia Ministerial, orgão máximo da OMC

Os membros iniciais poderiam ter sido as partes contratantes do GATT, de 1947. De um total de 124 Estados representados que aceitaram o novo acordo, 115 o firmaram e 109 o ratificaram. A União Européia, que por força de sua competência exclusiva em matéria de política comercial sucedeu

\footnotetext{
26 MANGAS MARTIN: 1996, p.343-sgs. IGLESLAS PRADA, 1997 [O , D.5.

27 BRASIL. Decrelo n." 1335 , de 30 dez. 1994 , promulgou a ata finat do Acordo de Marraqueche.

28 FYRNANDEZ DE LA GANDARA, 1997, p.61-62. MANGAS MARTIN, 1996, p.345.
} 
aos Estados-membros como parte do GATT, de 1947, e os seus 15 Estadosmembros, que também firmaram individualmente o Acordo constitutivo da OMC, sảo todos membros iniciais ${ }^{29}$. No caso do ADPIC, em que a competência da União Européia é compartida, ela dispōe dos votos de todos seus 15 Estados-membros ${ }^{30}$.

Outros Estados unidos por algum regime juridico de integração regional poderão aderir à OMC e seus Acordos. A admissão depende da aprovação de dois terços da Conferencia Ministerial, sendo um caso especial o Anexo 4 (regido por nomas próprias, inclusive de admissão, composto de vários acordos comerciais plurilaterais sobre: aeronaves civis, contratos públicos, produtos lácteos e carne bovina) que devido ao seu caráter setorial tem autonomia em relação aos demais acordos.

O Acordo da OMC, por ser constitutivo de uma organização intemacional, năo admite reservas. Os anexos sim, o que deve ser leito segundo as disposiçoes fixadas no próprio instrumento.

A OMC assenta-se sobre os princípios do multilateralismo, nação mais favorecida e proibição de discriminaçōes ${ }^{31}$.

\subsection{1- Principio do multilateralismo}

O principio do multilateralismo consiste na liberdade de comércio entre Estados, sem facilidades tarifárias diferenciadas para nenhum deles. Teoricamente, permite que cada um dos paises envolvidos seja beneliciado com os ganhos máximos dos seus agentes econômicos no comércio mundial, consideradas a especialização na divisão internacional do trabalho e a vantagem comparativa que os produtos oferecem, particularmente devida à tecnologia.

Este é o princípio considerado fundamental da $\mathrm{OMC}$, tendo em vista que a organização tem vocacão para a arbitragem de conflitos comerciais

29 Dados de set. 1995 lonnecidos por MANGAS MARTIN, 1996, p. 346.

30 DICTAMEN 1/O4, Trbunal de Justica das Commidades Europeias, de 15/21/94.

31 MANCAS MARTIN, 1996, p.347349. ICLESLS PRADA, 1997W, p.15 
internacionais entre paises e para evitar as medidas unilaterais que conceitualmente the são contrárias.

É questionável, entretanto, a autoridade que poderá cer a OMC para impor decisoes contrarias a eventuais medidas unilaterais que possam ser tomadas pelos Estados Unidos, porque o governo desse pais tem dado abundantes provas da sua capacidade para lancar mão de instrumentos juridicos nas horas em que se laz necessario proteger o seu mercado, lace as ofertas de produtos competidores, como ocorreu com muitas mercadorias provenientes da União Européla e do Japão, por exemplo. Entre as medidas protecionistas e unilaterais que radicionalmente aplica, está a transferência de abundantes ajudas publicas para a pesquisa e desenvolvimento tecnológico, que é vista como desleal por outros países que nảo lêm condiçōes de fomentar este tipo de investigação ${ }^{32}$.

\subsection{2- Principios de nação mais favorecida e proibição de discriminaçoes}

Segundo o principio de nacäo mais favorecida, as vantagens concedidas por um Estado-membro a outro, membro ou não da OMC, sera automaticamente válido para todos seus membros. Este princípio era a base do lve-cambismo do século XTX e infio do século XX. Previsto numa série de tratados, permitiu um nivel de liberdade de comércio que até então não se conhecia. No acordo do GATT, este principio, que figurava no artigo primeiro, era considerado fundamental ${ }^{3}$.

O principio de proibicão de discriminaçoes visa coibir as práticas politicas de comércio exterior dos governos de criação de estímulos ou desestimulos para a negociaçäo de determinados produtos, como por exemplo taxas alfandegárias diferenciadas por produtos, controle de câmbio etc. que tenham por objetivo facilitar ou dificultar o comércio com determinados países.

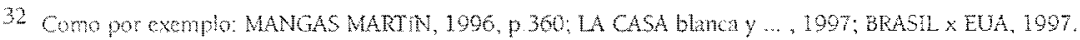

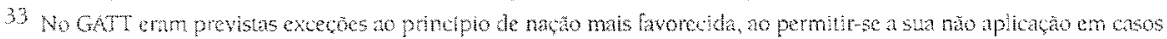

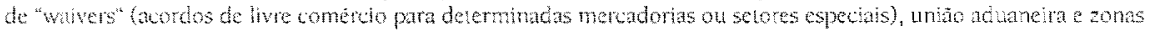

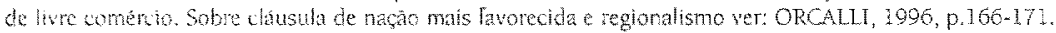




\subsection{3- Princípio da conservação do meio ambiente}

A conservação do meio ambiente é uma bandeira de luta que tende a manter-se desfraldada na sociedade atual. Os movimentos ecologistas dos paises do Primeiro Mundo, onde a degradação da natureza começou antes, têm sido bastante ativos na tentativa de promover a conscientização da população. Não obstante, ainda nào encontram respostas mais concretas por parte do povo enquanto consumidor, que segue comprando produtos que resultam de processos poluentes. Por outro lado, não conseguem obter um respaldo politico que se manifeste em normas ainda mais enérgicas e concretas que as existentes contra a poluição.

O Acordo de Marraqueche não poderia ficar ahelo ao tema ecológico, pois isso não seria "politicamente correto" diante da insistência das manifestaçoes de importantes setores da sociedade, de forma que foi inserido no seu preambulo um princípio norteador de respeito ao meio ambiente.

Com eleito, o Acordo reconhece que as relaçoes na estera das atividades metcantis e economicas, como um todo, devem tender a elevar os niveis de vida, permitindo ao mesmo tempo a utilização ótima dos recursos mundiais, em conformidade com o objetivo de um "desenvolvimento sustentável" que procure proteger e preservar o meio ambiente e incrementar os meios para fazê-lo. Como não poderia ser distinto, na lógica capitalista as medidas podem ser compatibilizadas com necessidades e interesses segundo os diferentes níveis de desenvolvimento economico ${ }^{34}$.

O fato dos paises não levarem o tema em consideração ficou bastante claro depois da reunião da ONU, ocorrida em Kyoto, Japão, no mês de dezembro de 1997, para tratar do meio ambiente, quando os Estados Unidos não respaldatam o projeto de intensificacão do controle da emissão de gases poluentes como era esperado, e, ao revés, com seu apoio os índices permitidos de emissão de gases seräo pouco reduzidos, além de contarem com um longo período para a sua aplicaçăo.

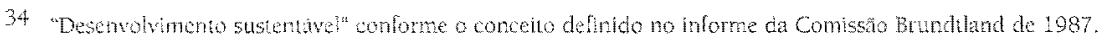


A grande interrogaçāo é saber se a sociedade estará em condiçōes de exigir a proteção que o meio ambiente requer, ou se sucumbirä aos interesses econômicos que não o permitem.

O "produto ecológico" necessita fundamentalmente de três coisas: tecnologias que permitam a produção com um minimo deterioro do meio ambiente; preferência dos consumidores e normas efetivas que proibam a produçăo contaminante. O que se observa em relaçăo às pessoas que decidem politicamente os destinos da sociedade, é que ainda não estão dispostas a assumir o custo econômico da proteçào ambiental, justificando essa omissão com a impossibilidade de contornar o encarecimento dos produtos que estas medidas provocariam.

Os paises do Terceiro Mundo, que indiretamente defendem os interesses dos agentes econômicos potenciais ou algumas vezes instalados sobre seus territorios, têm considerado a inclusão da dimensão ecológica da produção nos acordos internacionais, como o Acordo OMC, uma barreira ao seu desenvolvimento.

Assim, devido ao chamado "custo social" do produto ecológico, ficou acordado que a proteção do meio ambiente não deverá ser utilizada como pretexto para a adoção desproporcionada de medidas restritivas do comércio, que tenham outra finalidade que a de conseguir um desenvolvimento sustentavel, no marco de medidas coletivas de respeito aos acordos internacionais sobre conservação e não contaminação ${ }^{3 \%}$.

\section{6- Efeitos da constituição da $O M C$}

Os efeitos da constituição da OMC serão mais visiveis a partir do periodo 2000-2004, quando os calendários transitórios pactuados chegarão a termo, já que se relerem a numerosos setores.

No Informe Anual de 1997, da OMC, ficou registrado que:

(..) os governos Membros abordaram em 1997 uma ampla gama de questoes para que a OMC siga encamando um sistema normativo

35 GLWA nute mudr, $190 \%$

36 MANOAS MARTE, 1996, p.362. 
multilateral, dinâmico e valldo. (..) pondo em relevo algumas grandes tendências manifestadas pela politica comercial durante o ano 1997. Por exemplo, em 15 de fevereiro, 69 govemos aceitaram medidas de liberalização de vasto alcance para os serviços de telecomunicaçós básicas. Em 26 de março, 40 governos convieram em reduzir os direitos aduaneiros sobre os produtos de tecnologia da informação, começando em julho de 1997 e com o objetivo de eliminar todos os direitos sobre esses produtos no ano 2000. O comério intemacional em produtos de tecnologia da informaça representa uns US\$ 600.000 milhoes anuais, ao passo que o setor das telecomunicaçóes básicas geram uma suma similar em ingressos internos e internacionais.

O Informe dedica um capitulo inteiro para explorar a fundo a interaçăo entre politica comercial e politica de concorrência. Reconhecendo, também. o impacto desfavorável que podem ter na concorrencia as medidas comerciais dos governos, o capitulo se centra nos efeitos de restriçăo ou distorçáo do comércio que podem derivar-se das práticas empresarais. Se examinam nele os meios legais empregados a nivel nacional pelos governos para prevenir ou corrigir esse comportamento empresarial e as esferas em que seria possivel potencializar a cooperação internacional nesta matéria ${ }^{37}$.

Para lazer uma estimativa, considerando os dados do comércio intemacional disponiveis, referentes aos anos de 1989 e 1994 , respectivamente, observa-se que as maiores exportaçoes foram realizadas pela União Européia (15 e 16\%), Estados Unidos (12 e 16\%) e Japäo (9, le $5 \%$ ), enquanto o resto do mundo exportou 63,9 e 63\%. As maiores importaços foram realizadas pela União Européia (16,2 e 15\%), Estados Unidos (15,6 e 13\%), Japão (7 e 10\%), o resto do mundo importou $61,2 \mathrm{e}$ $62 \%^{2 \%}$.

37 OMC. Sectinn, PRESS/85, 8 de dictembre de 1997, thatphwww wo org/> acesso em 12 jan. 1098.

38 COMUNDADES EUROPEAS ... 2991, 2.27, 1997, ..34. 
Os eleitos econômicos do Acordo de Marraqueche já se manifestam pelo aumento das cifras do comércio internacional. Exemplificando, o comércio mundial de mercadorias cresceu 9\% em 1994, o triplo que em 1993 e mais alto desde 1976. As exportaçoes cresceram $12 \%$, sendo que a maior fatia coube às telecomunicaçoes, materiais de escritório e computadores que alcançaram. $11 \%$ do total das exportaçoes ${ }^{39}$.

Segundo MANGAS MARTIN, os periodos transitórios pactuados, como em geral os longos prazos para a aplicação do Acordo de Marraqueche, somando-se as questões pendentes, poderão atrasar por alguns anos os frutos dessa longa negociação para o crescimento econômico, quer dizer para a consolidaça do processo de mundialização do capitalismo, que de certa maneira era esperado para o linal do século $\mathrm{XX}^{40}$.

Tampouco poderiam ser esperadas consequências imediatas e positivas para todos os setores: alguns lucram primeiro e os outros acreditam nas possibilidades de lograrem seus beneficios a partir de algum momento e por isso trabalham. Os efeitos positivos na matemática econômica sāo condicionados por fatores como a capacidade de exportar dos agentes instalados nos Estados, das condições de competitividade, das condiçoes laborais, do comportamento dos monopólios, da abertura do mercado ao exterior, da garantia da patente e outros direitos intelectuais etc.

A liberalização beneficia, sobretudo, aos agentes econômicos que possuem capital e aos centros economicos onde se encontram instaladas as sedes das empresas. A batalha, a competição mais acirrada, o jogo decisivo, está delineado em termos de propriedade intelectual, especialmente a propriedade industrial. Dentro deste item destaca-se a biotecnologia (sobretudo fármacos); os serviços audiovisuais é informáticos e outros como o turismo e o lazer, software, bancos, seguros, intermediação monetária etc.

A importância sócio-econômica dos serviços se evidencia pelos índices do seu crescimento na economia internacional, que desde o ano de 1992 registra aumento superior ao valor do comércio de mercadorias. Levando em

39 MANGAS MARTN, 1996, 359. EL COMERCIO mundw de menandins ..., 1995, p.55.

AO MANCAS MARTH, 1996, p.359. 
consideraçäo respectivamente os anos de 1958, 1989 e 1993-1994, na União Européia passou de $39 \%$ a $61 \%$ e depois reduziu-se a $53 \%$, no Japāo, de $40 \%$ a $59 \%$ mantendo-se em 59\%, e nos Estados Unidos, onde mais se desenvolvem as redes e serviços intelectuais, foi de $58 \%$ a $70 \%$ e $73 \%$. Na antiga URSS passou de $35 \%$ para $41 \%$, sem dados posteriores ${ }^{4 l}$.

Não se pode considerar e nem comparar estes dados com os do mercado informal, onde se insere o mercado invisível de drogas e armamentos, que imagina-se movimentar riquezas do mesmo nível de grandeza do mercado formal ${ }^{42}$.

Cabe assinalar que a constituição da OMC beneficia aos países industrializados, antigos e novos, e que não enriquecerá os menos desenvolvidos. Isto é, o que se pode deduzir pelos dados colhidos. As exportaçōes realizadas pela Uniāo Européia, Estados Unidos e Japão alcançam em torno de $37 \%$ do total que o mundo vende, sobrando $63 \%$ para o restante. Quanto as importações, a União Européia, Estados Unidos e Japão compram $38 \%$ do que o mundo produz cabendo $62 \%$ ao restante ${ }^{43}$.

Se consideramos que no período havia uma população mundial estimada de 5.500 milhões de habitantes, sendo que na União Européia $(368,7)$, Estados Unidos $(258,3)$ e Japão $(124,7)$ somavam 751,7 milhões ou $13 \%$ - numa aproximação de dados: um décimo da população mundial compra e vende, quer dizer movimenta, mais de um terço do comércio ${ }^{4+}$.

A América Latina, que no seu conjunto constitui um aglomerado excessivamente heterogêneo e desequilibrado de países, apresentando níveis extremamente diferentes de potencialidades e de desenvolvimento, participava no comércio mundial, conforme dados de 1985 e 1990 , respectivamente, com $6,2 \%$ e $4,9 \%$ das exportações e $3,8 \%$ e $3,7 \%$ das importações. Para uma população de 433 milhões ${ }^{45}$.

\footnotetext{
41 COMUNIDADES EUROPFAS ..., 1991, p.19, e 1997, p.23. MANGAS MARTiN, 1996, p.359.

42 ROSA, 1996, D.3.

43 COMUNIDADES EUROFEAS ..., 1991, p.27, e 1997, p.34.

44 Dados populiacionais da União Européia, Fstados Unidos e Japão contidos no mapa "LA UNION Europea: Estados miembros, regiones y unidades adminisıralivas", publicação oficial da União Européia (1996), cillas de 1993.

45 JAGUARIBE, 1993, p.31. RELACÖES Comunidade Européia Anérica Latina, 1993, p.30.
} 
Os numeros anteriores, positivos para os mais industrializados, devidos aos potenciais efeitos que as reduçoes das taxas alfandegárias e a maior abertura dos mercados acarretaram, podem entretanto ser negativos para os paises do Terceiro Mundo, que necessitaräo ainda de certa proteção e vantagens em relaça aos demais, para que possam compensar as desigualclades do acesso aos mercados. Não obstante, alguns analistas estimam que o bilateralismo mercantil penalizaria mais aos países menos desenvolvidos que o atual sistema mululateral - o que entendemos ser bastante questionável ${ }^{46}$.

\section{7- Funçöes da OMC}

A funcão da OMC e estabelecimento das diretrizes de política comercial para os seus Estados-membros, quer dizer impor o que a oligarquia trilateral e os paises mais industrializados entenderem como necessáio à integraçäo comercial e aos processos de industrialização e mundialização.

Administra os acordos comerciais da OMC e serve de foro para negociaçes comerciais; trata de resolver as diferencas comerciais; supervisiona as politicas comerciais nacionais; presta assistência técnica e cursos de fomaçäo para os países em desenvolvimento; coopera com outras organizaçoes internacionais ${ }^{40}$.

\section{Acordo ADPIC}

Neste item analisaremos os direitos de propriedade intelectual relativos ao comércio que emanaram do Acordo de Maraqueche, enlocando as linhas gerais das "regras do jogo". Trata-se de um conjunto de nomas que asseguram o funcionamento dos direitos de propriedade intelectual em escala mundial. Embora alguns Estados permanecam fora do sistema, isto

\footnotetext{
46 MANGES MAETIN, $1996,0,359$

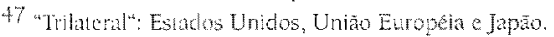

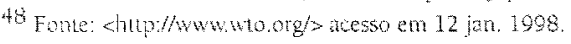


representa uma parcela "insignificante" em termos negociais. De forma que está constituído um sistema de propriedade especial, que por sua vez se insere no sistema mais amplo do comércio, a partir da contribuição significativa dos "donos do poder" ao processo de mundialização do capital.

O uso e o trálego mercantil da tecnologia protegida juridicamente pela patente abrangem agora desde a mecânica até a biologia, o que implica dizer que qualquer campo da tecnologia é patenteável. O espaço demandado para o debate ético sobre o tema é tão grande quanto às potencialidades e possibilidades da produção industrial tecnológica.

Possivelmente o homem econômico, aquele que é capaz de uma ação tão eficiente quanto "invisível", com as possibilidades do uso e potencialidades do lucro, com as garantias oferecidas pela propriedade intelectual, tenha ultrapassado a penúltima barreira na conquista das coisas que podem ser objeto de comércio. Talvez o que ficará pendente para este século XXI será a propriedade do corpo humano enquanto tal, e as espécies vegetais e animais.

Prevalecendo esta tendência de desenvolvimento, normatização e organização econômica as gerações de um futuro próximo poderão encontrar novamente no mercado formal, outros seres humanos, como se comprava um escravo. Assim, se poderá adquirir num supermercado um bom exemplar de humano, com os detalhes que mais satisfaçam aos desejos do consumidor, desde a garantia até a grife com marca registrada, além da promessa de que se nāo ficar satisfeito poderá devolver o produto e obter o reembolso do pagamento.

Há uma infinidade de questōes encobertas pelas possibilidades da propriedade industrial e pela colocação das coisas no comércio, com as respectivas implicações em vários âmbitos, como o político, o social, o econômico, o jurídico e o bioético.

O Acordo representa a tentativa mais ambiciosa de regular e proteger os diferentes bens imateriais em todo o mundo. É um acordo de grande envergadura e complexidade, não somente pelo conteúdo substantivo e adjetivo das novas normas, mas sim pelo enfoque global que á dado ao tema 
e pela vinculaçăo formal à vida econômica e comercial; significando uma mudança na evolução dos institutos da propriedade intelectual, novas interpretaçöes e novos atores ${ }^{40}$.

O Acordo ADPIC possuí dois mecanismos básicos para corrigir as práticas de infrações à propriedade intelectual: primeiro a elevação do nivel de proteção em todos os Estados-membros do acordo, segundo a garantia da observação dos direitos de propriedade intelectual através de procedimentos judiciais ágeis e efetivos ${ }^{50}$.

O ADPIC trata dos direitos de autor e conexos, marcas, indicações geográlicas de procedencia, desenhos industriais, patentes, topografias de circuitos integrados, proteção de informação confidencial e controle de práticas de concorrência desleal em contratos de licença; estabelece os princípios básicos, padróes relativos à existência, abrangência e exercicio dos direitos de propriedade intelectual, sobre aplicação destas nomas, sobre obtenção e manutenção destes direitos e procedimentos inter partes conexos, bem como a prevença e solução de controvérsias entre os Estadosmembros.

Consolida-se no Acordo a terminologia segundo a qual a propriedade intelectual é o gênero do qual os direitos de propriedade industrial e de autor são as principais espécies. No Brasil, a expressão propricdade intelectual se utilizava na linguagem legal e doutrinária para designar o Direito de Autor.

Antes de adentrar na discussāo do Acordo em si, para melhor entendê1o, é necessário conhecer os atores que participaram da sua produção.

\section{1- Negociação do Acordo ADPIC e seus principais atores}

Complementando as informações do item anterior, sobre o processo de negociaçöes no GATT, deve-se recordar que o Acordo ADPIC é o resultado da mudança de âmbito na produção das normas internacionais sobre a hamonização desse sistema juridico e que o enfrentamento Norte-

\footnotetext{
49 GOMEZ SEGADE, 1996, p.34 79. PORZIO, 1996, p.407. FERNANDEZ DE LA GANDARA, 1997, p.45 60. DACON, $199 \%, 13 \%-170$.

50 IGLESIAS PRADA, 1997 (b), D. 16.
} 
Sul, que marcou o debate sobre as reformas da Convenção de Paris, versão Estocolmo de 1967, atê chegar ao fracasso, se transladaram depois para o GAIT.

Por resolução da Assembléia Geral da ONU, a OMPI se integrou às Naçóes Unidas como a sua décima quarta organizaça especializada. Ao assumir a filosolia, estrutura e método de trabaho da ONU, a OMPI incorporou os efeitos das tensóes políticas entre os distintos grupos de países. Não obstante, o aperfeiçoamento e o controle da proteção internacional da propriedade intelectual permaneceu, pelo menos fomalmente, sob seu protagonismo ${ }^{51}$.

A principal finalidade da OMPI vinha sendo fomentar a proteção da propriedade intelectual em todo o mundo. As suas funçōes, para alcançar os fins nessa matéria, eram, entre outras, melhorar aquela proteção e harmonizar as legislaços nacionais, favorecer a conclusão de acordos internacionais, prestar assistência técnico-juridica e informaçöes, bem como Comentar estudos ${ }^{32}$.

O acondo original do GATT, por outro lado, não teve incidencia sobre a proteção internacional dos direitos de propriedade intelectual até a década de oitenta, orientado que estava para o comércio de produtos. Assim, a OMPI permaneceu como a instituição protagonista no campo da regulaçăo dos direitos intelectuais até o acordo final da Rodada Uruguai do GATT.

Desde os anos setenta se buscava uma reformulação profunda da propriedade intelectual, fruto de uma necessidade que se fez mais intensa nos anos oitenta, conformada por várias circunstancias de diferentes natureza: econômica, política e decorrentes das mudanças tecnológicas ${ }^{53}$.

No inicio da década de 1980 houve na OMPI uma grande reação dos paises subdesenvolvidos contra os prejuizos que thes acarretava o sistema vigente. Os conceitos em crise eram o da igualdade entre paises $e$ o da patente como um titulo de propriedade, decorrente de um direito natural. Os paises

\footnotetext{
51 Resilucito de 1712/1974. GÓMEZ SEGADE 1996, p.36.

52 Conencio de Fsocotmo, $147 / 1967$, que estabelece a OMPI, and $3^{*} \mathrm{e} 4^{\prime \prime}$.

53 GOMEZ SECADE, 1996, p.38.40.
} 
subdesenvolvidos exigiam tratamento preferencial em relaçäo aos desenvolvidos. Alegavam ser justo o tratamento desigual para os desiguais, reagindo contra o conceito de absoluta igualdade de direitos e deveres entre as naçoes. Assim, a revisão da Convenção de Paris foi levada ao impasse, pois um grupo que reunia 77 paises reivindicava tratamento preferencial para os seus nacionais e a introdução de cláusulas que permitissem um maior controle sobre abusos dos direitos de patente ${ }^{54}$.

Cada bloco defendia uma postura única, atuando com um potta-voz, ainda que os interesses dos seus membros nāo fossem coincidentes circunstäncia que näo poderia levar a nenhum avanço significativo para a reformulação da proteça à propriedade industrial, fracassando, assim, três sucessivas conferências para revisar a Convencăo da União de Paris ${ }^{55}$. Enquanto a OMPI passava por um periodo de letargia e burocratismo, sem aportar soluções eficazes e, por estar dominada pelos países menos desenvolvidos, era desacreditada pelos paises industrializados, em especial pelos Estados Unidos

A preocupação com a evolução da tutela jurídica da propriedade intelectual, como marco genérico, sempre loi mais presente nos países industrializados, que procuraram acomodála ao seu proprio desenvolvimento industrial e comercial, com o fim de manterem sua elicácia frente as novas situacōes que se foram apresentando nos diferentes campos, como no das marcas, dos direitos autorais requeridos pelas indústrias gráfica e cinematográlica, passando por vários outros campos e setores até chegar às patentes biotecnológicas ${ }^{5 h}$.

Pode-se ilustrar com um exemplo que dá uma boa idéia da dimensão do fenómeno. Apenas no mercado de medicamentos do Brasil se movimentava, antes de ser admitido o patenteamento no setor farmacológico, a cifra aproximada de US\$ 5 bilhöes anualmente, enquanto

\footnotetext{
S4 CARVAIHO, 1983. MMENTEL, 1999.

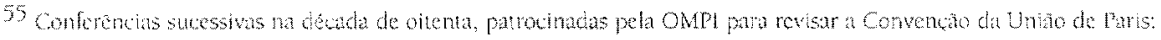
(rentura (1980), Naind (1981) Cenebra (1982).

56 pokz10, $1996,1.409$
} 
na Argentina era estimado em US\$ 5,3 bilhôes o comércio de medicamentos. As transnacionais (SANDOZ, ROCHE, SQUIBB, PFIZER, GLAXO, MERCK, RHODIA, BAYER, SCHERING etc.) com instalaçoes no Brasil alegavam a perda de US\$ 600 milhões por ano devido a falta de patentes dos seus produtos $^{57}$.

Os Estados Unidos inicialmente adotaram a politica de negociacóts bilaterais com diversos países onde havia protecão insuficiente para os direitos de propriedade intelectual, exigindo uma melhoria da situacao. Como mecanismo de persuasăo, condicionavam a concessão de preferencias comerciais ao incremento do nivel de protecá a propriedade intelectual, inclusive ameaçando com sançoes comerciais e aplicando-as eletivamente quando näo obtinham o retorno desejado. Esta politica acabou produzindo resultados que loram considerados insuficientes. Ademais, era uma atuacão de iniciativa unilateral, com uma consideravel carga de protecionismo, que foj muito criticada por outros paises industrializados ${ }^{58}$.

O Brasil, durante a fase de negociaçoes do ADPIC, viveu sob ameaça constante de "retaliaçoes" comerciais por parte dos Estados Unidos, inclusive sofrendo sançoes materializadas em medidas restritivas às importaçoes de produtos brasileiros, com grave impacto em sua economia, até que fosse adotada a patente biotecnológica que näo existia. O mesmo sucedeu a outros paises do Terceiro Mundo. A finalidade era óbvia: alcançar o maior dominio dos mercados intemos desses paises para lavorecer a industna norteamericana. Somente os muito ingênuos ou interessados acreditavam que usando das mais perversas formas de coaça para impor a adocão de uma nova legislaçäo de patentes, os norte-ameticanos estavam interessados no desenvolvimento tecnológico das naçoes amigas ${ }^{59}$.

57 KARAN, 1995, "ndustin gira..." p.4.50UZA, 1995, p.8. GALIO, 1995, p.4.

58 GOMEZ SEGADE, $1996, \mathrm{p} 40-41$

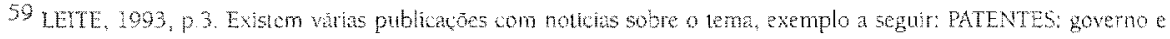

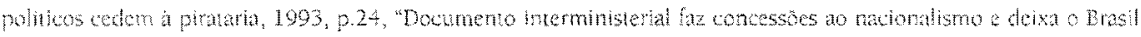

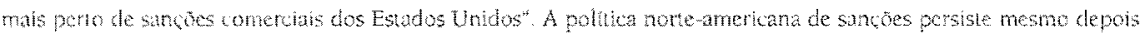

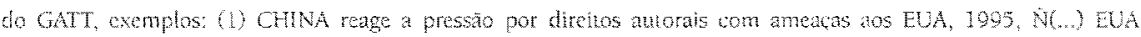

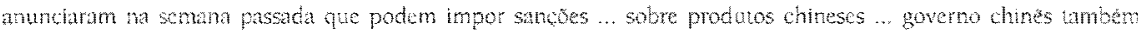

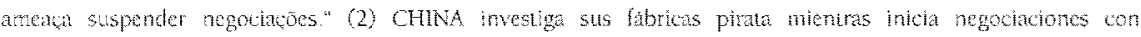

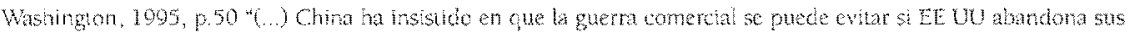


Para GOMEZ SEGADE, a estratêgia de imposição unilateral de determinados niveis de proteção, como era o caso da pressão mantida nas negociaçoes comerciais bilaterais, se tornou insatisfatória porque violava os compromissos assumidos no GATT e, além disso, originava uma Iragmentação da propriedade industrial no mundo todo. Pois haviam paises com maior ou menor nivel de proteção da propriedade intelectual segundo seu maior ou menor grau de resistencia às pressōes norte-americanas ou dos paises mais desenvolvidos.

O sistema intemacional era injusto, deste modo, porque nenhum pais estava em condiçôes de fazer exigências aos Estados Unidos ou à União Européla para suprirem as lacunas dos seus próprios sistemas na matéria. Além disso, era um sistema ineficiente por näo conseguir um avanç global e signilicativo na proteçäo da propriedade intelectual, posto que os acordos bilaterais ficavam obsoletos rapidamente e não se adaptavam às novas circunstancias das inovações tecnológicas. Basta verificar que o processo de revisão da Convencão da União de Paris iniciado em Genebra no ano de 1980 terminaria em Marraqueche quatorze anos depois ${ }^{\text {to }}$.

O processo de negociaçóes foi longo e complexo, dominado, como já refermos, pelo enfrentamento Norte-Sul, no qual os paises em vias de desenvolvimento mais ativos foram o Brasil e a india, porta-vozes do grupo cuja posição estratégica se viu debilitada depois da queda do muro de Berlim, em 1989, com a eliminação da tensão Leste-Oeste, que antes favorecia à oposiçăo. Depois, os paises da ex-URSS passaram a aspirar um lugar na Comunidade Economica Européia e mudaram os rumos da política extema. Entre os países desenvolvidos também ocorreram conflitos, principalmente em relação às denominaçōes de origem. Chegou-se ao ponto

peticiones excssivas y poo razonables." (3) EE UU aprueba el ingreso de Clinu en la Organizacon Mundial del Coménio. 1995, p.65. N( .) el wisto bueno ... forma parte del acuerdo sobre Derchos fle Propiedad tntelectual." (4)

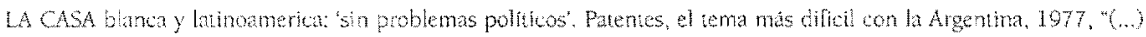
For el problema de patentes, Estados Unidos incluso sancione a la Argentina en marzo pasado (...). No més de Fevereiva de 2001 os Fstat os Unidos apresentou tenanda contra o Brasil ma OMC, devido ao problema das patentes de Farmitios.

60 GOMEZ SLGADE, 1996, p.42-43. Sobre a revisto da Convencto de Faris, versto Estocolmo de 1967 . BOGSCH, 1984, p.18-20, Nessa epma, quando do centenario da Conventa em 1983 , haviam 93 paises filiados a OMP. 
de considerar que, caso não fosse conseguido um acordo sobre os direitos de propriedade intelectual, a Rodada Uruguai não obteria resultados positivos, colocando em risco o futuro da mundialização e do sistema multilateral de conércio, caindo por terra também os benefícios que muitos paises estavam esperando por aceitarem as "regras do jogo" determinadas pelos gigantes econômicos"

Para PACÓN, o modesto poder de negociação que têm os paises em vias de desenvolvimento ficou demonstrado nas negociaços da Rodada Uruguai do GATT. O conflito Norte-Sul, entretanto, não teve o maior peso nas negociaçoes, que refletiram muto mais as diferenças e as necessidades de regulamentaçäo dos interesses dos paises industrializados. Somando-se ao fato de que os especialistas dos paises em vias de desenvolvimento praticamente não tomaram parte nas negociaçóes. Sendo registrado por vários analistas que os representantes da maioria da missỏes diplomáticas que participaram das tratativas não tinham os conhecimentos técnicojuridicos necessarios para defender os interesses dos respectivos paises ${ }^{62}$.

Os principais protagonistas da reformulação das normas internacionais de propriedade intelectual, deste modo, foram os países mais desenvolvidos, particularmente os integrantes da Uniäo Européia e os Estados Unidos, que adotaram medidas de pressăo para reprimir a pirataria e produzir instrumentos mais eficazes de proteção aos direitos de propriedade intelectual.

A estrutura global de negociacões da Rodada Uruguai do GATT, clepois da Declaracăo de Punta del Leste, em 1986, se estabeleceu pela integração de três orgãos: o Comilé de Negociaçóes Comerciais, encarregado da coordenação-geral das negociaçoes, o Grupo de Negociaçoes de Mercadorias e o Grupo de Negociaçoes de Serviços. Dentro do grupo de mercadorias foi instituido um subgrupo de negociaça para os aspectos dos direitos de propriedade intelectual relacionados ao comério, denominado

61 Ver BACON, $19 \%, \mathrm{p} .141$

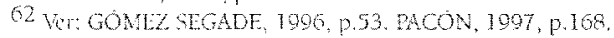


Grupo 11, presidido pelo sueco ANELI, que iniciou os trabalhos no ano de $1987^{6}$.

Os primeiros documentos de sugestóes e propostas foram apresentados pelos Estados Unidos e pela Uniăo Européia. Depois foi a vez do Japão, seguindo-se os documentos contendo as sugestões do movimento promovido por uma poderosa agrupação de mega-empresas, que publicou uma proposta de normas substantivas, com destaque para a restrição das possibilidades de concessão de licença obrigatória e eliminação da obrigação de explorar industrialmente o invento nos paises onde fosse obtida a patente $^{\text {hin }}$.

O texto final do $\mathrm{ADPIC}$, negociado por iniciativa dos Estados Unidos e contemplando os temas-chave conforme foram decididos pelas grandes potências comerciais, acabou sintetizado na proposta apresentada pela União Européia e depois firmada por uma centena de países. Portanto, é uma espécie de noma programática que impõe obrigaçoes de caráter substancial aos membros, que de modo geral obedece aos interesses dos Estados mais desenvolvidos e industrializados ${ }^{65}$.

\subsection{Por que um regime juridico minimo para a propriedade intelectual?}

O sistema internacional da propriedade intelectual até a constituição da OMC estava composto por uma série de elementos dispersos: as legislaçōes nacionais de propriedade intelectual, a Convenção da União de Paris, a Convenção de Berna, os tratados regionais, além de instituiçóes como a OMPl, as decisões dos tribunais administrativos e judiciais de diferentes niveis e a prảica das relaçóes negociais internacionais ${ }^{\text {hit }}$.

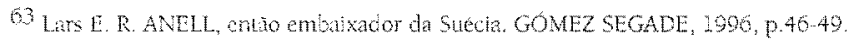

64 "Bastc Ftamework of GATT Rrovisions on Intetecual Property statement of views of the European, Japonesc and Unicd Sale Business Communites". GOMEZ SEGADE, 1996, p.47.

65 MANGAS MARTN, 1996, p.357. TUGORES QUES, 1996, p.237. FERNANDEZ DE LA GANDARA, 1997, p.70; A

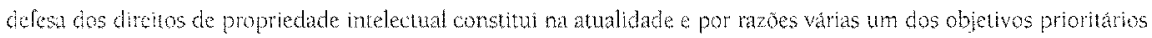
cos parses industratizados. IGLESIAS PRADA, 1997[a], p.131. OTERO GARCLA.CASTRILLON, 1997, p.414.

66 PORZIO, 1996, p.408.
} 
As normas internacionais da propriedade intelectual passaram por vários estágios e revisōes, num contínuo processo de transformaçăo. 0 mesmo ocorreu com a instituiçăo internacional encarregada da coordenação dos aspectos administrativos decorrentes dessas normas como se esboçou em ítem precedente.

No que toca ao aspecto econômico, o destaque dado pela política comercial à proteção da propriedade intelectual como um elemento nuclear foi decomência da crescente globalização da economia e sobretudo aos avanços tecnológicos. Com efeito, a produção industrial foi mudando sua base para os setores vinculados à pesquisa e criatividade, sendo que a inovaçăo se tornou central na filosofia empresarial e fator determinante do exito no universo da competição e concorrência entre empresas. Ocorreu, como consequência, uma mudança também dos ciclos econômicos, que passaram a ser cada vez mais curtos.

Mas o fato económico relevante e fundamental, neste contexto, foi a inserção de um número crescente de empresas no mercado internacional, operando a escala global. Como consequencia, a circulação e o sucesso comercial de muitas mercadorias desencadeou também a pirataria, que por sua vez provocou o aumento das tensões entre os paises industrializados com sistema de proteção da propriedade intelectual e aqueles paises emergentes onde o sistema era menos desenvolvido ou inexistente, jä que os direitos de propriedade intelectual constituem um elemento competitivo de primeira grandeza. Deste modo, os problemas de nivel microeconômico passaram a ser macroeconómicos, ao produzirem efeitos negativos nas balanças de pagamentos dos paises mais desenvolvidos, sempre que empresas competiam com aquelas dos paises onde a proteção não era adequada

No âmbito politico intemacional também ocorreram fatos relevantes para a mudança do contexto de proteção à propriedade intelectual. A tensão politica entre blocos provocou que os enfrentamentos passassem para todos

67 COMEZ SEGADE, 1996, p.38-39. 
os âmbitos e instituiçoes, entre elas a OMPI. Mantiveram-se nela as confrontaçŏes Leste-Oeste, que foram diminuindo com a mudança de rumo da antiga Uniāo Soviética, e Norte-Sul, entre os países desenvolvidos e o grupo dos 77 menos desenvolvidos ${ }^{68}$.

Sob a óptica das mudanças tecnológicas, houve em várias áreas uma Cacilidade de utilização e reprodução rápida de todo tipo de criaça, tornando os titulares de direitos de propriedade intelectuais mais vulneráveis e sem que houvesse um incremento paralelo dos meios defensivos. Foi nos setores industriais das comunicaçoes e informaçōes, onde há predominância de bens imateriais e altos lucros, onde se produziram as maiores mudancas tecnológicas sem a correspondente proteção jurídica.

No âmbito social também houve transformaçöes, tanto na mentalidade dos empresários, como nos hábitos dos consumidores. E as empresas perceberam, mais do que antes, que a propriedade intelectual era um ativo valioso e que as licenças de exploraça podiam se converter em importante lonte de ingresso.

Desta forma, na segunda metade da década cle 1980, uma grande interdependência no comércio e a necessidade de integração das diversas políticas e nomativas a seu respeito, tomavam indispensável um enfoque global da tutela juridica da propriedade intelectual e uma solução para seus principios essencialmente territoriais num momento em que as fronteiras perdiam aceleradamente importância. Isto porque o comércio e a propriedade intelectual possuem intima relaça, particularmente com o comércio intemacional, campo onde as instituiçoes juridicas da propriedade intelectual resultaram insuficientes e incapazes de solucionar problemas práticos

Ao ser feita a redaçäo do instrumento do Acordo ADPIC houve a preocupação de consignar quais eram os "desejos" dos membros, quanto aos efeitos que se esperavam do mesmo, para evitar distorçoes na interpretação - o que ficou expresso no seu preàmbulo.

GS GOMEZ SEGADE, 1996, p.39.

68 PORZL, 1996, P.410. PMENTEL 2000 
Assim, a razão de ser do ADPIC foi a redução das distorções e obstáculos ao comércio internacional pela eliminação das suas causas, entre estas a ineficaz e inadequada proteção aos direitos de propriedade intelectual. Por sua vez, que essas medidas e procedimentos destinados a fazê-los respeitar, não viessem a se tomar, depois, obstáculos ao comércio legítimo.

Para tanto, havia a necessidade de um conjunto de novas regras que contivesse alguns atributos, explicitados a seguir: primeiro, que incorporasse os princípios básicos do GATT, de 1994, e dos acordos e convençôes intemacionais relevantes em matéria de propriedade intelectual; segundo, que estabelecesse padröes e princípios adequados no tocante à existència, abrangència e exercicio dos direitos de propriedade intelectual relacionados ao comércio; terceiro, que estabelecesse meios eficazes e apropriados para a aplicaça das normas em tela, levando em consideraçăo as diferenças dos sistemas juridicos nacionais; quarto, que previsse procedimentos eficazes e expeditos para a prevenção e solução multilateral de controvérsias entre governos; quinto, que contivesse um arcabouço de princípios, regras e disciplinas multilaterais sobre o comércio de bens falsificados, sancionando essa prätica anacrônica de concorrência.

No preâmbulo do Acordo ADPIC ficaram expressos, também, os seus pressupostos básicos: que os direitos de propriedade intelectual são direitos privados; e, que os sistemas nacionais para a proteçăo da propriedade intelectual e os objetivos de desenvolvimento e tecnologia dos governos, são objetivos básicos de politica pública. Os paises de menor desenvolvimento relativo, membros, deveriam contar com mais flexibilidade para implementarem internamente leis e regulamentos, de forma a habilitá-los a criar uma base tecnológica sólida e viável.

Por fim, foi ressaltada a importância de reduzir tensões, mediante a obtenção de compromissos mais firmes para a solução de controvérsias, como será possivel com as regras contidos no Acordo ADPIC, por meio de procedimentos multilaterais. E de estabelecer relações de cooperação mútua entre a OMC e a OMPI, bem como, com outras organizações internacionais relevantes. 
Estabelecidas as premissas, a primeira obrigação assumida pelos membros do Acordo ADPIC foi a de colocar em vigor as regras nele contidas pelos procedimentos previstos em seus respectivos sistemas e práticas jurídicas de ordem nacional. Fsta obrigação internacional se refere a proteçăo contida no Acordo como um padrão mínimo, nada menos, e inclusive o que vier a ser acrescentado, o plus, näo deve contrariar as suas disposicoes. Assim, loi alcancado um conjunto de preceitos juridicos para ser aplicado de modo unilorme em escala global.

\section{3- Objetivos do Acordo ADPIC}

O objetivo primordial do Acordo ADPIC é gatantir de modo harmonizado, um patamar de proteção minima para os direitos de propriedade intelectual nos mercados dos países desenvolvidos ou de economias emergentes. O que consistirá em lacilitar as exportaços dos paises mais industrializados, criando ao mesmo tempo as condiçoes necessárias de segurança jurídica para um eventual mercado de translerencia de tecnologia no luturo ${ }^{70}$.

Em consonancia com o discurso de reconhecimento, expresso no seu preâmbulo, que diz serem objetivos básicos de política pública dos sistemas nacionais para a proteção da propriedade intelectual, inclusive os objetivos de desenvolvimento e tecnologia, loi estabelecido no Acordo ADPIC que:

A proteço e a aplicaça de normas de proteça do direitos de propriedade intelectual devem contribuir para a promoçäo da inovaçäo tecnológica $e$ para a ransferencia e difusäo de tecnologia, em beneficio mituo de produtores e usuários de conhecimento lecnologico e de uma forma conducente ao bem-estar social e economico e a um equilibrio entre direitos cobrigacoes?

\footnotetext{
70 MACAS MARTIN 1096, p.356. OTTEN, 1997, p.23: Antende que A Atordo ADPTC na lem por obicto ser um iando de hamonizatio, porque pode cumprir as obrigacos minimas astabelecendo con liberdade o método

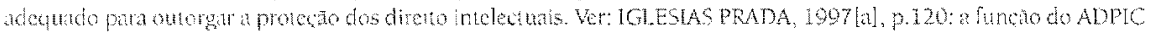

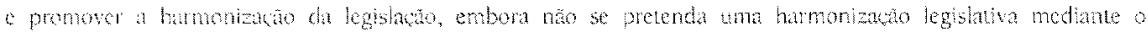

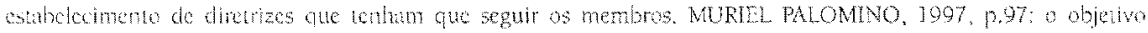

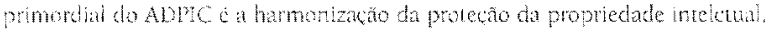

71 Aroth ADTC, ari.

72 FERNANDFZ DE LA GANDARA, 1997, P.71.
} 
O objetivo, sobretudo, é que a tutela dos direitos de propriedade intelectual não se converta, de fato, em um obstáculo ao comércio internacional ${ }^{72}$.

Assim, como observa GOMEZ SEGADE, o único objetivo é a extensão e incremento do nível de proteção dos direitos de propriedade intelectual em todo o mundo. Proteção que se estendeu muito do ponto de vista quantitativo, tendo em vista que até abril de 1997 o número de paises que formavam parta da OMC ascendia a 13i. para os quais é vinculante o que prescreve o ADPIC. O resultado pode ser facilmente constatado pela comparação entre o texto do ADPIC, por exemplo, no que trata de propriedade industrial e a nova lei brasileira de propriedade intelectual.

\section{Conclusäa}

As normas juridicas do comércio mundial têm como principal centro de produção legislativa internacional a OMC. A organização foi estabelecida com esta finalidade, resultado da Rodada Uruguai de Negociaçoes Comerciais Multilaterais do GATT. Os interesses protegidos pelas nomas são àqueles dos paises mais industrializados, que tiveram e têm condiçôes de barganhar e lograr o consenso para sua aprovação entre os membros da organização.

O exemplo que bem ilustra essa afirmação é o acordo sobre a propriedade intelectual. Os paises em desenvolvimento e, principalmente, os paises menos desenvolvidos ainda näo possuem tecnologias e nem conhecimentos, nos diferentes campos da economia, que possam justificar o aprofundamento e amplitude das regras jurídicas do setor.

Inexoravelmente, todavia, o Brasil é um país aberto ao comércio e membro da OMC, subscreveu a ata final do GATT e o acordo internacional da sua constituiçà, cujo efeito é a obrigaça internacional de acatar suas normas e incorporá-las ao direito interno.

72 FEWNANEEZ DE LA GANDARA, 1997, p.71. 
Resta, assim, para os juristas, estudar o complexo ordenamento juridico do comércio internacional para a adequada interpretação e aplicação dos direitos económicos no ámbito da jurisdição nacional, especialmente o mercantil.

\section{BIBLIOGRAFIA}

BARRAL, Welber. A OMC e acordo anti-dumping. In: PROENCA, Alencar Mello, BOCCA, Stella (Orgs.). A integraça rumo ao século XXI: V Encontro Internacional de Direito da América do Sul (Buenos Alres, Jumho de 1996). Pelotas: EDUCAT, 1996.

BOGSCH, Arpad primer centenario del Convenio de París para la protecion de la propiedad industral Actas de Derecho Industrial 1983, Madid, CUEF-CSP, t.9, p.13-52, 1984.

BRASL $\times$ EUA. Folha de S.Paulo, Säo Panlo, 13 mato 1997

CAPELA, Juan Ramon. Fruta prohibida: una aproximación histórico-teorética al estudio del deredzo y de? Estalo. Madrid: Trota, 1997.

1) CARVAIHO, Nuno Tomaz Pire de 0 sistena brasileiro de patentes: o mito e a realidade. RDMIEF, Săo Prulo, vXXll-nova scrie, n.52, outhdez. 1983.

2) CHINA mvestiga sus fábricas piratas mientras inicia negociaciones con Washington. El Pais, Madrid, 16 feb. 1995 p. p.50.

3) CHINA reage a pressâo por diretos autorais com ameaças aos EUA. Folha de S.Paulo, Sá paulo, 5 jan. 1997.

CLMA năo muda. Folha de S.Paulo, São Pat:lo, 13 dez. 1997.

1) COMUNIDADES EUROPEAS. Europa de los doce: cifas clave. Luxemburgo, CC-AD-91-007-ES-C, 1991.

COMUNDADES EUROPEAS. Europa de los quince: cifras clave. Luxemburgo, CM-97-96-798-ES-C, 1997

1) EEUU apruba ol ingreso de China en la Organizacion Mundial de Comercio. E1 Pais, Madid, 13 mar. 1995. p. 65 .

EL COMERCIO mundial de merancias crecio un $9 \%$ en 1994, el riple que en 1993. El Pais, Madrid, 9 mayo 1995 . p. 55

FERNANDEZ DE LA GANDARA, Luis. La ronda Uruguay y et GAI; análisis y perspectivas. In: 1GLESIAS PRADA, Juan Luis (Dir). Los derechos de propiedade intelectual en la OMC: el Acuerdo sobre los ADPC. Madrid: CEFIDEI, 1997 . t.1

GADBAW, R. M. Intelectual property and international trade: metger or marrage of convenience? Vanderbilt Joumal of Transnational Law, y.22, n.2, 1989.

GALLO, Ritr. Empresa nacional defende a "Pirataria". Gazeta Mercantil são Paulo, Relatorio, p.4, 5 maio 1995. 
GOMFZ SEGADE, José Antonio. El acuedo ADPLC como nuevo marco para la proteción de la propicdad industrial e intelectzal. Actas de Derecho Industrial y Derecho de Autor 1994-95. Madrid: Marcial Pons, 2.16, p.33-79, 1996.

IGLESAS PRADA, Juan I.uis. Disposiciones generales y principios basicos en el acuerdo sobre los ADPC. In: IGLESIAS PRADA, Juan I wis (Dix). Los derechos de propiedade intelectual en la OMC: el Acnerdo

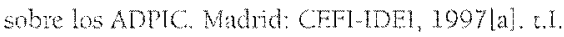

Presenucion. In: IGLESIAS PRADA, Juan Luis (Dir). Los derechos de propiedade intelectual en la OMC: A Acterdo sobre los ADPIC Nadrid: CEFI-[DEI, 1997[b] t t.

JAGUARIR: Helio Significaço do MERCOSUL. In: MERCOSUL: sinopse estatistica. Rio de Janeiro: IBGE, 1993.

KARAN, Rita Lndistria gra US\$ 5 bilhoes por ano no Brasil: as multinacionais dominam $70 \%$ da receita gerata pelo setor lamacentico, calcula o presidente da Interfama Gazeta Mercantil, Să Panto, Relatono, $0.4,5$ mato 1995.

LA CASA blanea y lanowmerica, "sin problemas poîticos": patertes, el tena más dificil con la Argentina. Clarin, Buchos Aves, smayo 1907.

LA OT avisa que los problemas cn Asia pueden generar caos social en la region. Ll Pais, Mudrid, 12 dic. 1997 p.59

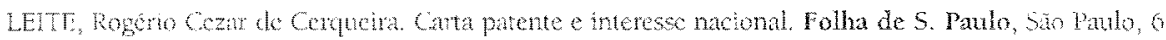
mar. 1993. Opinian, n. 3 .

LOBTO GARCMMIAN, Mantw. Las disposiciones an materia de patentes del acucrdo sobre los ADPC, Mn: IGUSAS RRADA, Jun Luis (DH) Los derechos de propiedade intelectual en la OMC: Acurelo sobre bs ADPIC Madrid: CEFI-IDE!, 1997. LI.

MANGASMARTIN, Aracli Otras organizaciones universales de fines espechicos. In DIEZ DE VILASCO VALLEJO, Mantel Las organizaciones internacionales. 9 ed feimpressionl. Madrid: Tecnos, 1990. MASAGUER FUENTES, Jose. Los derechos de propiedad industrial e intelectual ante el derecho comunitario: lilve circulacion de merancias y defensa de la competencia. Madrid: CEFLIDEI, 1995.

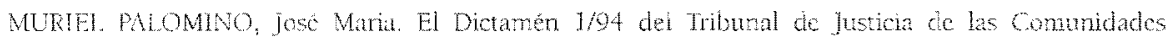
Furopens solye el reparto de competencias entre la Commidad y sus Estados miembros en la conclusión del Acucro OMC: especial referencia al Acterdo sobre los ADPTC. In: IGLESAS PRADA, Juan Luis (Dir). Los derechos de propiedade intelectual en la OMC: Cl Acuerdo sobre los ADPIC. Madrid: CFPI. IDEI, 7997, 1.1.

ORCAL LY, Gabricl. Tendencia al regionalismo y garantia de aceso a los merados. In PROLNCA, Alenca Melo; BloCCA, stella (Orgs.). A integraca rumo ao seculo XXI: V Encontro Internacional de Dirito da America do sul (Buenos Aitcs, Junho de 1996). Pelotas: EDUCAT, 1996.

OTERO GARCiA CASTRILLON, Camon. Las patentes en el comercio intermacional. Madrid: Dykinson, 1997

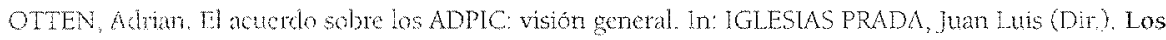
derechos de propiedade intelectual en la OMC: el Acuerdo sobre los ADPIC. Madrid: CFEI-IDEI, 1997. t.

PACON, Ana Mara ADPTC y los paises en vas de desarollo posicion durante y despues de la konda Urugnay In: IOLISAS RRADA, Jum Luis (Dir). Los derechos de propiedade intelectual en la OMC: d Acurewo sobre los ADPIC. Madrid: CHI-IDE, 1997. t.1.

DATENTES: Govemo politicos cedem a pitria. Exame, Să Paulo, 31 mar. 1993. p.24 
PMENTEl, Luiz Otwo. Chile e Mercosul: relacoes com anião Europeia e bero-América en assuntos de tecnologia. In: IRIGOIN BARRENNE, Jeannette. Chile y el Mercosur en América Latina: VI Encuentro Intemacional de Derecho de América del Sur." Santago: Editorial Juridica de Chile, 1999. 1. 2, p. $765 \% 77 \%$.

Direito Industrial: as funçoes do direito de patentes. Porto Alegre: Stntese, 1999. : aspectos introdutorios. Chapeco: UNOESC, 1994.

Las funciones del derecho mundial de patentes. Cordoba (Argentina): Advocatus, 2000.

Ias relaciones de la Unón Europea con América del Sur y el pape! de Espana. IV Encuentro Internacional de Derecho de América del Sur, Montevideo, 18 may 1995

processo de mundializaço e produço das nomas juridicas para o comércio: o caso da propriedade industrial. Revista Jurídica da Universidade Estadual de Ponta Grossa, Fonta Grossa, v 2. p. $257-285$, jan./un. 1998.

Propriedade intelectual. In: BARRAL, Weber (Ong). O Brasil e a OMC: os interesses brasileiros

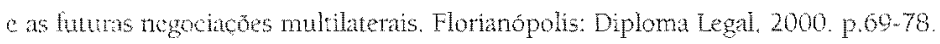

porzIO, Marino La propiedad intelectal y la nueva Organizacion Mundial de Comerio. In: HOMENAJE a Julio Delicado Montero-Rios. Barcelona: Alppl, 1996.

RELACOES Comunidade Européia América Latina. Luxemburgo: Divisa de Infomacio, de Publicacócse de Relacoes com os Meios Socioprofissionats, 1993. 46 p. CES-93-001-PT:

ROSA, Luz Pingueli. Ciencia e tecnologia, engenhara e emprego. Folha de S. Paulo, Săo Paulo, 18 out 1906. Opinita. p.3.

SANDON, Paulo (Org). Dicionário de economia. 8.ed. Sho Paulo: Best Seller, 1994

SoUZA. Jorge Luiz de. A votaço da nova lei sera apos as elecocos a quedande-braco entre os laboratoros nacionais os estrangeivo cquivale a un mercado de US\$ 5,3 bilhoes por ano. Gazeta Mercantil, Sa Pando, Rutatón, p.8, 5 mino 1995

TAMAMES, Ramon; GALLGG, Santiago. Diccionario de economia y finanza. Madrid: Altanza, 1996. TUGORES QUES, Juan. Economfa internacional e integración económica. 2.ed. [3.ed. 1997] Madrid: MeGraw-Hill, 1995.

ZUCCHLRTN, Dand R. MTELMAN, Carlos O. Marcas y patentes en el GATT: regimen legal. Bucnos Aires: Abeledo-Penot, 1997. 